\title{
Preparation and characterization of protein isolate from Yellowfin tuna Thunnus albacares roe by isoelectric solubilization/ precipitation process
}

\author{
Hyun Ji Lee', Gyoon-Woo Lee ${ }^{1}$, In Seong Yoon ${ }^{1}$, Sung Hwan Park' , Sun Young Park², Jin-Soo Kim²
} and Min SoO Heu ${ }^{1 *}$

\begin{abstract}
Isoelectric solubilization/precipitation (ISP) processing allows selective, pH-induced water solubility of proteins with concurrent separation of lipids and removal of materials not intended for human consumption such as bone, scales, skin, etc. Recovered proteins retain functional properties and nutritional value. Four roe protein isolates (RPIs) from yellowfin tuna roe were prepared under different solubilization and precipitation condition (pH 11/4.5, pH 11/5.5, pH 12/4.5 and pH 12/5.5). RPIs contained 2.3-5.0 \% moisture, 79.1-87.8 \% protein, 5.6-7. $4 \%$ lipid and 3.0-3.8 \% ash. Protein content of RPI- 1 and RPI-2 precipitated at pH 4.5 and 5.5 after alkaline solubilization at pH 11, was higher than those of RPI-3 and RPI-4 after alkaline solubilization at pH $12(P<0.05)$. Lipid content (5.6-7.4\%) of RPIs was lower than that of freeze-dried concentrate (10.6\%). And leucine and lysine of RPIs were the most abundant amino acids (8.8-9.4 and 8.5-8.9 g/100 g protein, respectively). S, Na, P, K as minerals were the major elements in RPIs. SDS-PAGE of RPIs showed bands at 100, 45, 25 and $15 \mathrm{~K}$. Moisture and protein contents of process water as a 2'nd byproduct were 98.9-99.0 and 1.3-1.8\%, respectively. Therefore, yellowfin tuna roe isolate could be a promising source of valuable nutrients for human food and animal feeds.
\end{abstract}

Keywords: Protein isolate, Roe, Yellowfin tuna, Chemical composition, Isoelectric solubilization/precipitation process

\section{Background}

Processing of raw fish into food products generates large quantities of byproducts such as scales, head, viscera and roes. Byproducts utilization will improve the economic aspects of processing industry and further their nutritional beneficiation through valuable essential amino acid and fatty acid components (Narsing Rao et al. 2012). It has been estimated that the value addition of human food developed from the byproduct will increase significantly in the future (Kristinsson and Rasco 2000; Tahergorabi et al. 2012).

Yellowfin tuna Thunnus albacares is a large epipelagic species widely distributed in the tropical and subtropical

\footnotetext{
* Correspondence: heu1837@dreamwiz.com

'Department of Food and Nutrition/Institute of Marine Industry, Gyeongsang National University, Jinju 52828, Korea

Full list of author information is available at the end of the article
}

waters of the major oceans (Collette and Nauen 1983; Zudaire et al. 2013). Due to its high demand, yellowfin is harvested widely, and many types of fishing gear are used. Yellowfin tuna is widely used in raw fish dishes. And yellowfin tuna roe, a byproduct generated from fish processing (1.5-3.0 \% of total weight), is generally used as animal feed or pet food preparation (Chalamaiah et al. 2013; Klomklao et al. 2013; Intarasirisawat et al. 2011). In our previous study, we fractionated inhibitors from fish roes, and confirmed the distribution of protease inhibitory activity in crude extracts from fish roes (Ji et al. 2011; Kim et al. 2013a; 2013b). In the present study, yellowfin tuna roe was used as a model for fish processing byproduct, and it was the starting material for isoelctric solubilization/precipitation (ISP). ISP process is to solubilize the muscle protein at low or high $\mathrm{pH}$ to separate soluble proteins from bone, skin, connective 
tissue, cellular membranes, and neutral storage lipids through the centrifugation (Nolsøe and Undeland 2009). The solubilized proteins are recovered by isoelectric precipitation to give a highly functional and stable protein isolate (Kristinsson and Ingadottir 2006; Chanarat and Benjakul 2013). The ISP processing has been applied to beef and fish processing byproducts (Chen and Jaczynski 2007a; 2007b; Mireles DeWitt et al. 2002). Various methods of protein isolate preparation have been reported for different protein sources, including legumes (Horax et al. 2004), oilseeds (Horax et al. 2011), cereals (Agboola et al. 2005; Ju et al. 2001; Paraman et al. 2007) and fish protein (Azadian et al. 2012; Chanarat and Benjakul 2013) based on solubility behavior of their proteins. Proteins isolates are the basic functional components of various high protein processed food products and thus determine the textural and nutritional properties of the foods. These properties contribute to the quality and sensory attributes of food systems (Foh et al. 2012). The roe of marine sources are the most underutilized fish by-products, which have considerable chance for value-addition to produce food and feed. Roes are easily decomposed with short shelf-life and hence, the roes should be processed immediately or converted into value added foods to enhance their shelf-life (Narsing Rao et al. 2012).

No scientific information is available on the protein isolate preparation from yellowfin tuna roe. The aims of this study was to investigate the chemical compositions, amino acid profile, mineral profile, color from yellowfin tuna protein roe isolate and second by-products with isoelectric solubilization/precipitation using basic and acidic $\mathrm{pH}$ treatments.

\section{Methods}

\section{Raw material}

Yellowfin tuna Thunnus albacares (YT) roe was obtained from Dongwon F\&B Co., Ltd. (Changwon, Korea). Roe was stored at $-70{ }^{\circ} \mathrm{C}$ in sealed polyethylene bags, and transferred to the laboratory. Frozen roe was partially thawed for $24 \mathrm{~h}$ at $4{ }^{\circ} \mathrm{C}$ and then cut into small pieces with an approximate thickness of $1.5-3 \mathrm{~cm}$ and minced with food grinder (SFM-555SP, Shinil Industrial Co., Ltd., Seoul Korea). Minced roe was frozen at $-20{ }^{\circ} \mathrm{C}$ until used.

\section{Chemicals}

Bovine serum albumin (BSA), casein, hemoglobin, $\beta$-Mercaptoethanol $(\beta-\mathrm{ME})$, glycerol, $\mathrm{N}, \mathrm{N}, \mathrm{N}^{\prime}, \mathrm{N}^{\prime}$-tetramethyl ethylene diamine (TEMED), sodium carbonate, sodium hydroxide, sodium L-tatarate, and potassium hydroxide were purchased from Sigma-Aldrich Co., LLC. (St. Louis, MO, USA). Copper (II) sulfate pentahydrate was purchased from Yakuri Pure Chemicals Co., Ltd. (Kyoto, Japan). Bromophenol blue and Folin-Ciocalteu's reagent were purchased Junsei Chemical Co., Ltd. (Tokyo, Japan). All reagents used analytical grade.

\section{Preparation of roe protein isolates (RPIs)}

The frozen minced roe was homogenized with distilled deionized water (DDW) at a ratio of 1:6 (w/v) using a homogenizer (POLYTRON ${ }^{\bullet}$ PT 1200E, KINEMATICA AG, Luzern, Switzerland). The homogenate was adjusted to $\mathrm{pH} 11$ and 12 with $2 \mathrm{~N} \mathrm{NaOH}$, respectively. Alkaline solubilization was solubilized protein and inactivated endogenous enzymes in the homogenate. Once the desired $\mathrm{pH}$ was reached, the solubilization reaction was allowed to take place at $4^{\circ} \mathrm{C}$ for $1 \mathrm{~h}$, followed by centrifugation at $12,000 \mathrm{~g}$ and $4{ }^{\circ} \mathrm{C}$ for $30 \mathrm{~min}$ using a refrigerator centrifuge (Supra $22 \mathrm{~K}$, Hanil Science Industrial Co., Ltd., Incheon, Korea). After centrifugation, two alkaline solubles ( $\mathrm{pH} 11$ and 12) in the supernatant fraction, and two alkaline insolubles ( $\mathrm{pH} 11$ and 12) as processing 2'nd byproduct in the precipitate fraction were separated. First, to prepare the protein isolates from alkaline solubles through acid precipitation, those of $\mathrm{pH}$ were readjusted by addition of $2 \mathrm{~N} \mathrm{HCl}$ to $\mathrm{pH} 4.5$ and 5.5, respectively, a value near the isoelectric point of fish proteins. The suspensions were centrifuged at $12,000 \mathrm{~g}$ and $4{ }^{\circ} \mathrm{C}$ for $30 \mathrm{~min}$. After centrifugation, the supernatants were collected as roe process waters (RPWs) and referred to as RPW-1 (pH 11/4.5), RPW-2 (pH 11/5.5), RPW-3 (pH 12/4.5) and RPW-4 (pH 12/5.5), respectively. Precipitates by alkali solubilization and acid precipitation were additionally washed with DDW by centrifugation at $12,000 \mathrm{~g}$ and $4{ }^{\circ} \mathrm{C}$ for $30 \mathrm{~min}$ to remove the $\mathrm{NaCl}$. After centrifugation, the washed roe protein isolates (RPIs) were lyophilized and referred to as RPI-1 (pH 11/4.5), RPI-2 (pH 11/5.5), RPI-3 (pH 12/4.5), and RPI$4(\mathrm{pH} 12 / 5.5)$, respectively. The roe protein isolate washed water (RPI-WW) as the 2'nd byproduct referred to as RPI-WW1 (pH 11/4.5), RPI-WW2 (pH 11/5.5), RPI-WW3 (pH 12/4.5) and RPI-WW4 (pH 12/5.5), respectively. Alkaline insolubles were resuspended with DDW, then readjusted to $\mathrm{pH} 6.5$ with $2 \mathrm{~N} \mathrm{HCl}$, and centrifuged at $12,000 \mathrm{~g}$ and $4{ }^{\circ} \mathrm{C}$ for $30 \mathrm{~min}$. The supernatants were collected and referred to as roe alkaline insoluble washed water (RAI-WW11 and RAI-WNW12, respectively). The precipitate was lyophilized and referred to as roe alkaline insolubles (RAI-1 and RAI-2, respectively). All samples were stored at $-20{ }^{\circ} \mathrm{C}$ until further experiments. A flow chart for the preparation of roe protein isolates (RPIs) is shown in Fig. 1.

\section{Proximate composition}

The proximate composition was determined according to the AOAC method (AOAC 1995). Moisture content was determined by oven-drying method at $105^{\circ} \mathrm{C}$ until a constant weight was reached. The ash content was obtained 


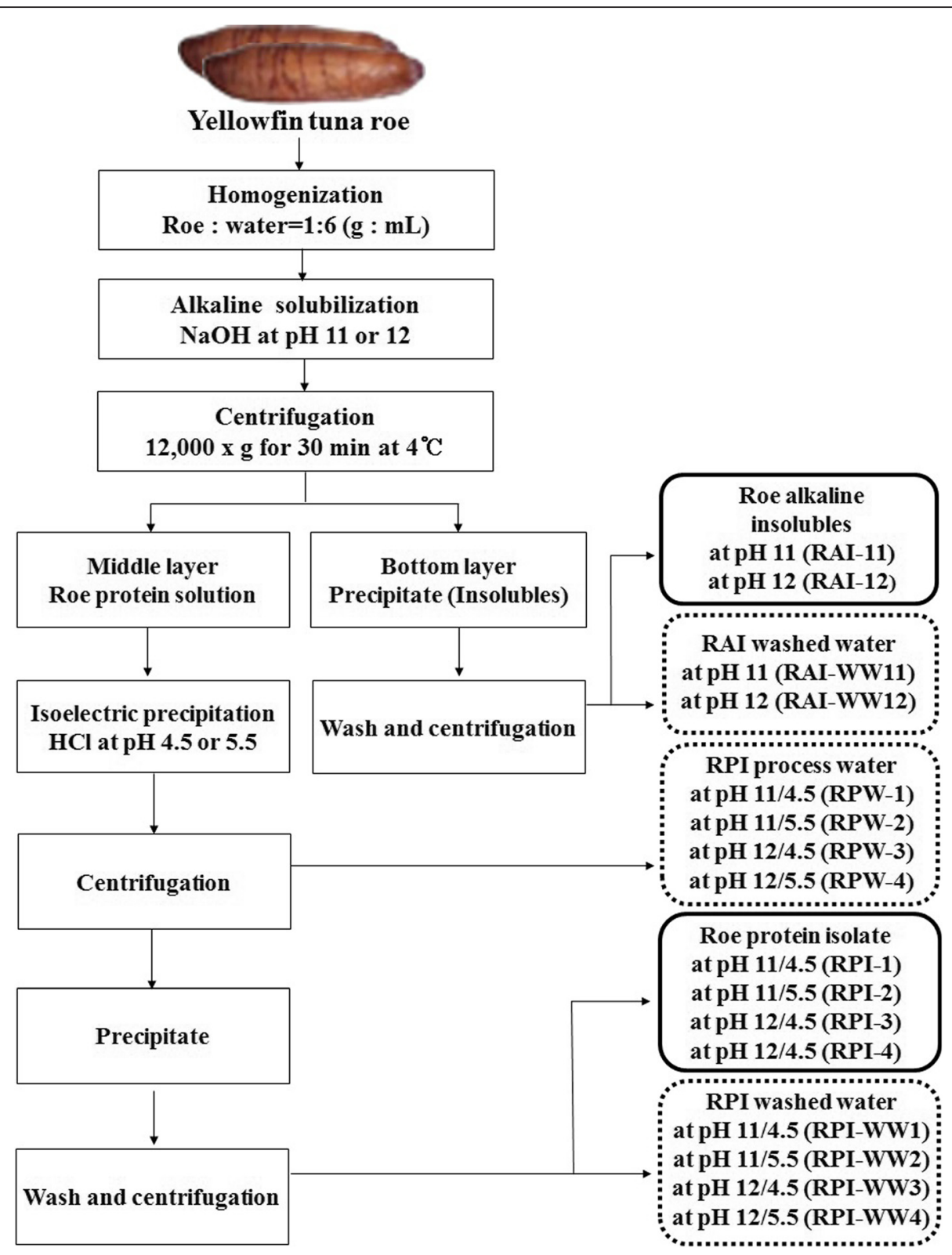

Fig. 1 A flowchart for recovery of yellowfin tuna roe protein isolates using isoelectric solubilization and precipitation process

by ashing a sample in a muffle furnace (Thermolyne 10500 furnace, a subsidiary of Sybron Co., Dubuque, IA, USA) at $550{ }^{\circ} \mathrm{C}$ until a constant final weight for ash was achieved. The total crude protein $(\mathrm{N} \times 6.25)$ content of samples was determined using the semi-micro Kjeldahl method. Total lipid content was determined according to the Soxhlet extraction method.

\section{Protein concentration}

Soluble protein concentration of sample was determined by the method of Lowry et al. (1951) using bovine serum albumin as a standard.

\section{Total amino acid}

Total amino acid analysis was conducted according to AOAC method (AOAC 1995). The sample $(20 \mathrm{mg})$ was hydrolyzed with $2 \mathrm{~mL}$ of $6 \mathrm{~N} \mathrm{HCl}$ at $110{ }^{\circ} \mathrm{C}$ for $24 \mathrm{~h}$ in heating block (HF21; Yamoto Science Co, Tokyo, Japan) and filtered out using vacuum filtrator (ASPIRATOR A-3S, EYELA, Tokyo, Japan). Amino acids were quantified using the amino acid analyzer (Biochrom 30, Biochrom Ltd., Cambridge, United Kingdom) employing sodium citrate buffers $(\mathrm{pH} 2.2)$ as step gradients. The data are reported as $\mathrm{mg}$ of amino acid per $100 \mathrm{~g}$ of protein. 


\section{Mineral}

Analysis of iron $(\mathrm{Fe})$, copper $(\mathrm{Cu})$, manganese $(\mathrm{Mn})$, cadmium $(\mathrm{Cd})$, nickel $(\mathrm{Ni})$, lead $(\mathrm{Pb})$, zinc $(\mathrm{Zn})$, chromium $(\mathrm{Cr})$, magnesium $(\mathrm{Mg})$, sodium $(\mathrm{Na})$, phosphorus $(\mathrm{P})$, potassium $(\mathrm{K})$, calcium $(\mathrm{Ca})$, and sulfur $(\mathrm{S})$ contents in sample was carried out using the inductively coupled plasma optical emission spectrophotometry (OPTIMA 4300 DV, Perkin Elmer, Shelton, Conn., USA). Briefly, teflon digestion vessel was washed overnight in a solution of $2 \%$ nitric acid (v/v) prior to use.

Sample was dissolved in $10 \mathrm{~mL}$ of $70 \%$ nitric acid. The mixture was heated on the hot plate until digestion was completed. The digested samples were added in $5 \mathrm{~mL}$ of $2 \%$ nitric acid and filtered using filter paper (Advantec No. 2, Toyo Roshi Kaisha, Ltd., Tokyo, Japan). Sample was massed up to $100 \mathrm{~mL}$ with $2 \%$ nitric acid in a volumetric flask

\section{Hunter color}

Hunter color properties of samples were equilibrated to room temperature for $2 \mathrm{~h}$ prior to the color measurement. Colors were determined using color meter (ZE2000 Nippon Denshoku Inc., Japan). The colorimeter was calibrated by using a standard plate $\left(L^{*}=96.82\right.$, a* $=-0.35$, $\left.b^{*}=0.59\right)$ supplied by the manufacturer. The values for the CIE (Commission Internationale d'Eclairage of France) color system using tristimulus color values, L* (lightness), $\mathrm{a}^{*}$ (redness), and $\mathrm{b}^{*}$ (yellowness) were determined. The whiteness was calculated by the following equation:

$$
\text { Whiteness }=100-\sqrt{\left(100-L^{*}\right)^{2}+a^{* 2}+b^{* 2}}
$$

\section{SDS-PAGE}

The molecular weight distribution of protein isolates and their 2'nd byproducts was observed by sodium dodecyl sulfate polyacrylamide gel electrophoresis (SDS-PAGE) according to the method of Laemmli (1970). Briefly, $10 \mathrm{mg}$ of sample was solubilized in $1 \mathrm{~mL}$ of $8 \mathrm{M}$ urea solution containing $2 \% \beta$-mercaptoethanol and $2 \%$ sodium dodecyl sulfate (SDS) solution. Protein solution was mixed at $4: 1(\mathrm{v} / \mathrm{v})$ ratio with the SDS-PAGE sample treatment buffer (62.5 mM Tris-HCl (pH 6.8), $2 \%$ SDS (w/v), $10 \%$ glycerol, $2 \% \beta$-mercaptoethanol and $0.002 \%$ bromophenol blue) and boiled at $100{ }^{\circ} \mathrm{C}$ for $3 \mathrm{~min}$. The sample $(20 \mu \mathrm{g}$ protein) was loaded on the Any $\mathrm{KD}^{\mathrm{rm}}$ Mini-PROTEAN ${ }^{\circ}$ TGX ${ }^{\mathrm{TM}}$ Precast gel (Bio-Rad Lab., Inc., Hercules, CA, USA) and subjected to electrophoresis at a constant current of $10 \mathrm{~mA}$ per gel using a Mini-PROTEAN ${ }^{\odot}$ Tetra cell (BioRad Lab. Inc., Hercules, CA, USA). Electrophoresed gel was stained in $0.125 \%$ Coomassie brilliant blue R-250 and destained in $25 \%$ methanol and $10 \%$ acetic acid until background was clear. Molecular weight of protein bands was estimated using Precision Plus Protein $^{\text {TM }}$ standards (10-250 K, Bio-Rad Lab., Inc., Hercules, CA, USA).

\section{Statistical analysis}

All experiments were conducted in triplicates. The average and standard deviation were calculated. Data were analyzed using analysis of variance (ANOVA) procedure by means of the statistical software of SPSS 12.0 KO (SPSS Inc., Chicago, IL, USA). The mean comparison was made using the multiple range Duncan's test $(P<0.05)$.

\section{Results and discussions}

\section{Proximate composition}

Roe protein isolates (RPIs) from yellowfin tuna roe were prepared according to previously described ISP process. Proximate compositions of RPIs and positive controls (casein and hemoglobin) are shown in Table 1. Yields of RPIs prepared from YTR by ISP process were in range of $11.6-14.1 \%$ with slight difference. Moisture content of the RPIs ranged 2.3 to $5.0 \%$ RPI-1 (87.8\%) had the highest protein content than RPI-2 (83.2\%), RPI-4 (79.6\%) and RPI-3 (79.1\%), respectively $(P<0.05)$. protein content of RPIs was but lower than hemoglobin (94.4\%, $P<0.05)$. Protein content of RPIs were higher than that reported for fish protein powders obtained from different raw materials (Sathivel et al. 2004, 2005, 2006; Sathivel and Bechtel 2006; Shaviklo et al. 2011). Protein powder prepared from fish roe or surimi (Sathivel et al. 2009; Huda et al. 2001) had similar to protein content. Lipid (5.6-7.4\%) and ash content (3.0-3.8 \%) of RPIs were lower than those of FDC $(P<0.05)$. Pires et al. (2012) reported that mineral and fat were eliminated in the supernatant obtained after ISP process. Protein content of RPI- 1 and -2 precipitated at $\mathrm{pH} 4.5$ and 5.5 after alkaline solubilization at $\mathrm{pH} 11$, was significantly higher than those of RPI-3 and -4 after alkaline solubilization at $\mathrm{pH} 12(P<0.05)$. Whereas, yield of RPI- 1 and -2 was lower than that of RPI-3 and -4 . In this result, total protein yield of all RPIs was not significantly different $(P>0.05)$. Final supernatant referred to roe process water (RPW) as 2'nd byproduct was generated through alkaline solubilization and acid precipitation. Their moisture and protein contents are shown in Table 2. Moisture content of the RPWs ranged from 98.9 to $99.0 \%$ and protein concentration $(\mathrm{mg} / \mathrm{mL})$ of RPWs ranged from 2.6 to $3.0 \mathrm{mg} / \mathrm{mL}$. RPW-1 and RPW-3 (1478.5 and $1420.9 \mathrm{mg}$, respectively) had lower total protein than RPW-2 and RPW-4 (1861.2 and $1605.3 \mathrm{mg}$, respectively) in this experiment. Lower total protein of supernatant (RPW-1 and -3) obtained by acid precipitation at $\mathrm{pH} 4.5$ could be more efficient to raise the yield of RPI as precipitate, compared with protein isolate at $\mathrm{pH}$ 5.5. Roe alkaline insoluble-washed waters (RAI-WWs) and roe protein isolate-washed waters (RPI-WWs) were obtained through washing process to 
Table 1 Proximate composition of FDC, roe alkaline insolubles (RAls) as 2'nd byproducts and roe protein isolates (RPIs) by isoelectric solubilization and precipitation (ISP) process

\begin{tabular}{|c|c|c|c|c|c|c|}
\hline Sample & Yield $^{\mathrm{a}}(\mathrm{g})$ & Protein yield $^{\mathrm{b}}(\mathrm{g})$ & Moisture (\%) & Protein (\%) & Lipid (\%) & Ash (\%) \\
\hline FDC & 25.3 & 18.3 & $4.3 \pm 0.1 \mathrm{de}$ & $72.3 \pm 0.4 \mathrm{~h}$ & $10.6 \pm 0.1 b$ & $5.7 \pm 0.5 a$ \\
\hline RAl-11 & 8.7 & 7.1 & $6.5 \pm 0.1 b$ & $82.5 \pm 0.2 d$ & $10.2 \pm 0.1 b c$ & $2.0 \pm 0.0 \mathrm{c}$ \\
\hline RAI-12 & 8.0 & 5.9 & $10.1 \pm 0.2 a$ & $73.7 \pm 0.2 \mathrm{~g}$ & $13.1 \pm 0.5 a$ & $2.3 \pm 0.10$ \\
\hline RPI-1 & 12.6 & 10.1 & $4.7 \pm 0.1 \mathrm{~cd}$ & $87.8 \pm 0.7 b$ & $6.1 \pm 0.2 d$ & $3.8 \pm 0.2 b$ \\
\hline RPI-2 & 11.6 & 9.7 & $3.4 \pm 0.1 \mathrm{e}$ & $83.2 \pm 0.7 e$ & $7.4 \pm 0.1 c$ & $3.2 \pm 0.1 c$ \\
\hline RPI-3 & 14.1 & 11.1 & $2.3 \pm 1.5 \mathrm{ef}$ & $79.1 \pm 0.5 f$ & $5.6 \pm 0.1 d$ & $3.2 \pm 0.3 c$ \\
\hline RPI-4 & 13.4 & 10.6 & $5.0 \pm 1.8 c$ & $79.6 \pm 0.7 f$ & $6.3 \pm 1.0 d$ & $3.0 \pm 0.1 c$ \\
\hline Casein & - & - & $4.0 \pm 0.2 d$ & $85.5 \pm 0.0 c$ & - & - \\
\hline Hemoglobin & - & - & $2.0 \pm 0.0 f$ & $94.4 \pm 0.4 a$ & - & - \\
\hline
\end{tabular}

FDC freeze-dried concentrate; RAI-11 and RAl-12, roe alkaline insolubles after alkaline solubilization at pH 11 or 12 respectively. RPI-1 and RPI-2, roe protein isolate adjusting at $\mathrm{pH} 4.5$ and 5.5, respectively, after alkaline solubilization at $\mathrm{pH} 11$; RPI-3 and RPI-4, roe protein isolate adjusting at pH 4.5 and 5.5 , respectively, after alkaline solubilization at $\mathrm{pH} 12$

Data are given as mean values \pm SD $(n=3)$

Means with different letters within the same column are significantly different at $P<0.05$ by Duncan's multiple range test

-; not determined

${ }^{a}$ Yield is weight $(\mathrm{g})$ of roe protein isolate obtained from $100 \mathrm{~g}$ of raw YTR

${ }^{\mathrm{b}}$ Protein yield $(\mathrm{g})=$ yield $\mathrm{x}$ protein $(\%)$

reduce remaining salt in RAI and RPI. Their moisture and protein content are shown in Table 3. Moisture content of all washed water was ranged from 99.5 to $99.7 \%$ with no difference. Total protein of RAI-WWs in range of 315.0$340.3 \mathrm{mg}$ was higher than that of RPI-WWs in range of 133.5-192.4 mg). During ISP process, it was possible to recover more than $90 \%$ of the process water (RPWs, RAIWWs and RPI-WWs) contained $0.50-3.4 \mathrm{mg} / \mathrm{mL}$ protein.

\section{Total amino acid}

Total amino acid composition (g/100 g protein, \%) of RPIs, RAIs, and positive controls (casein and hemoglobin) are shown in Table 4. Protein content of all samples ranged from 81.6 to $96.3 \%$ on a dry base. From the result, RPIs had a EAAs/NEAAs acid ratio in range of 1.08 to 1.17. These were higher than that (0.92) of casein, but slightly lower than that (1.33) of hemoglobin. Leucine
(8.8-9.4\%), lysine (8.5-8.9\%) and isoleucine content (5.8-6.3 \%) of RPIs were significantly higher than those of RAIs $(P<0.05)$. It is indicated that total essential amino acid content of RPIs in range of $51.9-53.9 \%$ were higher than that (47.1-49.0\%) of RAIs. Intarasirisawat et al. (2011) reported that leucine $(8.28-8.64 \%)$ and lysine (8.24-8.30 \%) were the predominant essential amino acids in defatted tuna roe from skipjack, tongol and bonito. Lysine is often considered a first limiting amino acid for cereal food. Therefore, it needs to be emphasized that the RPIs had a higher content of lysine than egg white $(8.2 \%)$ $(P<0.05)$. The lysine content of RPIs was higher than that reported for Channa (6.94 \%) and Lates $(6.86 \%)$ roe protein concentrates (Narsing Rao et al. 2012). The major non-essential amino acids (NEAAs) of RAIs as 2'nd byproduct by alkaline solubilization were glutamic acid (13.7-13.8 \%), aspartic acid (8.8-8.9 \%) and arginine (6.4-6.6 \%),

Table 2 Moisture and protein contents of roe process waters (RPWs) obtained from yellowfin tuna roe during isoelectric solubilization and precipitation (ISP) process

\begin{tabular}{lccccc}
\hline Sample & Moisture (\%) & Protein $(\%)$ & Volume $(\mathrm{mL} / 100 \mathrm{~g}$ roe $)$ & Protein $^{\mathrm{a}}(\mathrm{mg} / \mathrm{mL})$ & Total protein $(\mathrm{mg})$ \\
\hline RPW-1 & $99.0 \pm 0.2 \mathrm{a}$ & $1.5 \pm 0.1 \mathrm{~b}$ & $547.6 \pm 0.0$ & $3.7 \mathrm{bc}$ & 1478.5 \\
RPW-2 & $98.9 \pm 0.1 \mathrm{a}$ & $1.8 \pm 0.0 \mathrm{a}$ & $547.4 \pm 0.0$ & $3.4 \mathrm{a}$ & 1861.2 \\
RPW-3 & $98.9 \pm 0.0 \mathrm{a}$ & $1.3 \pm 0.0 \mathrm{c}$ & $546.5 \pm 0.0$ & $2.6 \mathrm{c}$ & 1420.9 \\
RPW-4 & $98.9 \pm 0.0 \mathrm{a}$ & $1.6 \pm 0.1 \mathrm{~b}$ & $535.1 \pm 0.4$ & $3.0 \mathrm{~b}$ & 1605.3 \\
\hline
\end{tabular}

RPW-1 and RPW-2, roe process water adjusting $\mathrm{pH} 4.5$ and 5.5, respectively, after alkaline solubilization at $\mathrm{pH} 11 ; \mathrm{RPW}-3$ and $\mathrm{RPW}-4$, roe process water adjusting $\mathrm{pH} 4.5$ and 5.5, respectively, after alkaline solubilization at $\mathrm{pH} 12$

Values are means \pm standard deviation of triplicate determinations

Means with different letters within the same column are significantly different at $P<0.05$ by Duncan's multiple range test

a'Based on Lowry's method (1951) 
Table 3 Moisture and protein contents of roe alkaline insoluble washed waters (RAI-WWs) and roe protein isolate washed waters (RPI-WWs) by a washing process

\begin{tabular}{|c|c|c|c|c|c|}
\hline Sample & Moisture (\%) & Protein (\%) & Volume (mL/100 g roe) & $\operatorname{Protein}^{\mathrm{a}}(\mathrm{mg} / \mathrm{mL})$ & Total protein $(\mathrm{mg}$ \\
\hline RAI-WW11 & $99.5 \pm 0.1 a$ & $0.3 \pm 0.0 a$ & 262.5 & $1.21 \pm 0.0 \mathrm{a}$ & 315.0 \\
\hline RAI-WW12 & $99.5 \pm 0.0 a$ & $0.3 \pm 0.2 a$ & 283.6 & $1.16 \pm 0.0 b$ & 340.3 \\
\hline RPI-WW1 & $99.7 \pm 0.1 a$ & $0.2 \pm 0.0 \mathrm{a}$ & 320.6 & $0.58 \pm 0.0 c$ & 192.4 \\
\hline RPI-WW2 & $99.7 \pm 0.1 a$ & $0.2 \pm 0.0 \mathrm{a}$ & 352.3 & $0.47 \pm 0.0 e$ & 176.2 \\
\hline RPI-WW3 & $99.7 \pm 0.1 a$ & $0.2 \pm 0.0 \mathrm{a}$ & 317.1 & $0.48 \pm 0.0 \mathrm{de}$ & 158.6 \\
\hline RPI-WW4 & $99.7 \pm 0.2 \mathrm{a}$ & $0.2 \pm 0.3 a$ & 266.9 & $0.53 \pm 0.0 \mathrm{~d}$ & 133.5 \\
\hline
\end{tabular}

RAI-WW11 and RAI-WW12, roe alkaline insoluble washed waters of RAI-11 and RAI-12, respectively

RPI-WW1-4, roe protein isolate washed water of RAls (1-4)

Values are means \pm standard deviation of triplicate determinations

Means with same letters within the moisture (\%) and protein (\%) are not significantly different at $P>0.05$, and means with different letters within the protein concentration are significantly different $P<0.05$ by Duncan's multiple range test

a Based on Lowry method (1951)

Table 4 Total amino acid (g/100 g protein) composition of FDC, RAls and RPIs prepared by ISP process and positive controls

\begin{tabular}{|c|c|c|c|c|c|c|c|c|c|}
\hline Amino acid & FDC & RAI-11 & RAI-12 & RPI-1 & RPI-2 & RPI-3 & RPI-4 & Casein & $\mathrm{Hb}$ \\
\hline Protein content (\%) & $81.6 d$ & $87.2 \mathrm{c}$ & $82.8 d$ & $89.9 b$ & $86.9 c$ & $90.1 \mathrm{~b}$ & $89.5 b$ & $89.1 b$ & $96.3 \mathrm{a}$ \\
\hline Asp & $8.7 d$ & $8.9 \mathrm{~cd}$ & $8.8 \mathrm{~cd}$ & $9.3 b$ & $9.1 \mathrm{bc}$ & $9.3 b$ & $9.2 b$ & $8.2 \mathrm{e}$ & $11.2 \mathrm{a}$ \\
\hline$T_{h r}^{b}$ & $5.0 \mathrm{e}$ & $5.1 \mathrm{ab}$ & $5.0 \mathrm{~d}$ & $5.1 \mathrm{abc}$ & $5.1 \mathrm{ab}$ & $5.1 \mathrm{a}$ & $5.0 \mathrm{~cd}$ & $3.9 \mathrm{~g}$ & $4.7 f$ \\
\hline Ser & $5.6 a$ & $5.3 c$ & $5.4 b$ & $5.2 \mathrm{~cd}$ & $5.2 d$ & $5.4 b$ & $5.0 \mathrm{e}$ & $4.0 \mathrm{~g}$ & $4.4 f$ \\
\hline Glu & $13.1 d$ & $13.8 \mathrm{~b}$ & $13.7 \mathrm{c}$ & $12.7 e$ & $12.4 \mathrm{~h}$ & $12.4 \mathrm{~g}$ & $12.5 f$ & $22.1 \mathrm{a}$ & $9.3 i$ \\
\hline $\operatorname{Pro}^{c}$ & $6.1 \mathrm{c}$ & $7.7 b$ & $7.9 \mathrm{~b}$ & $5.7 d$ & $5.1 \mathrm{e}$ & $4.7 \mathrm{~g}$ & $4.9 \mathrm{ef}$ & 10.0a & 4.0de \\
\hline Gly ${ }^{c}$ & $4.9 c$ & $6.0 \mathrm{~b}$ & $6.4 a$ & $4.5 \mathrm{ef}$ & $4.2 f$ & $4.3 \mathrm{ef}$ & $4.3 \mathrm{ef}$ & $2.4 \mathrm{~g}$ & 4.6de \\
\hline $\mathrm{Ala}^{\mathrm{C}}$ & $6.6 c$ & $6.1 d$ & $6.2 d$ & $6.7 \mathrm{bc}$ & $6.9 \mathrm{~b}$ & $6.8 \mathrm{~b}$ & $6.8 \mathrm{bc}$ & $3.8 \mathrm{e}$ & $9.0 a$ \\
\hline Cys & $0.7 \mathrm{~b}$ & $0.8 b$ & $1.1 \mathrm{a}$ & $0.8 \mathrm{~b}$ & $0.9 b$ & $0.3 d$ & $0.2 d$ & $0.5 c$ & $0.1 d$ \\
\hline $\mathrm{Val}^{\mathrm{bc}}$ & $6.3 d$ & $6.7 c$ & $6.3 \mathrm{~cd}$ & $6.5 \mathrm{~cd}$ & $6.5 \mathrm{~cd}$ & $6.6 c$ & $6.6 \mathrm{~cd}$ & $7.3 b$ & $10.2 \mathrm{a}$ \\
\hline$M e t^{b c}$ & $2.9 \mathrm{c}$ & $2.5 \mathrm{~d}$ & $2.5 d$ & $2.9 \mathrm{~b}$ & $3.0 \mathrm{~b}$ & $3.1 \mathrm{a}$ & $3.1 \mathrm{a}$ & $1.3 e$ & $0.0 f$ \\
\hline$\| e^{b c}$ & $5.4 d$ & $4.9 e$ & $4.5 f$ & $5.8 \mathrm{c}$ & $6.2 \mathrm{ab}$ & $6.1 b$ & $6.3 a$ & $5.7 c$ & $0.8 \mathrm{~g}$ \\
\hline Leu $^{\mathrm{bc}}$ & $8.6 f$ & $8.0 \mathrm{~g}$ & $7.5 \mathrm{~h}$ & $8.8 \mathrm{e}$ & $9.3 c$ & $9.3 \mathrm{bc}$ & $9.4 b$ & $9.1 d$ & $13.3 \mathrm{a}$ \\
\hline Tyr & $3.4 a$ & $2.6 c$ & $3.4 \mathrm{a}$ & $3.2 b$ & $3.1 \mathrm{~b}$ & $3.4 \mathrm{a}$ & $3.2 \mathrm{~b}$ & $1.2 d$ & $0.3 e$ \\
\hline Phe ${ }^{b c}$ & $4.4 \mathrm{~h}$ & $4.6 f$ & $4.3 i$ & $4.5 \mathrm{~g}$ & 4.7e & $4.8 d$ & $4.9 c$ & $5.0 b$ & $7.6 a$ \\
\hline $\mathrm{His}^{\mathrm{b}}$ & $3.4 b$ & $3.2 c$ & $3.1 \mathrm{c}$ & $3.2 \mathrm{c}$ & $3.1 \mathrm{c}$ & $3.1 \mathrm{c}$ & $3.2 \mathrm{C}$ & $2.9 d$ & $6.4 a$ \\
\hline Lys $^{b}$ & $8.5 c$ & $7.6 \mathrm{e}$ & $7.3 f$ & $8.5 c$ & $8.9 b$ & $8.8 \mathrm{~b}$ & $8.9 b$ & $8.3 d$ & $10.3 a$ \\
\hline $\operatorname{Arg}^{b}$ & $6.6 a$ & $6.4 a$ & $6.6 a$ & $6.6 a$ & $6.4 a$ & $6.4 a$ & $6.5 a$ & $4.4 b$ & $3.8 \mathrm{c}$ \\
\hline TAA & 100.2 & 100.2 & 100.0 & 100.0 & 100.1 & 99.9 & 100.0 & 100.1 & 100.0 \\
\hline EAA & 51.1 & 49.0 & 47.1 & 51.9 & 53.2 & 53.3 & 53.9 & 47.9 & 57.1 \\
\hline EAA/NEAA & 1.04 & 0.96 & 0.89 & 1.08 & 1.14 & 1.14 & 1.17 & 0.92 & 1.33 \\
\hline Hydrophobic amino acid & 45.2 & 46.5 & 45.6 & 45.4 & 45.9 & 45.7 & 46.3 & 44.6 & 49.5 \\
\hline
\end{tabular}

TAA total amino acid, EAA essential amino acids, NEAA non essential amino acids

FDC freeze-dried concentrate; RAI-11 and RAI-12, roe alkaline insolubles after alkaline solubilization at pH 11 or 12 respectively. RPI-1 and RPI-2, roe protein isolate adjusting at $\mathrm{pH} 4.5$ and 5.5, respectively, after alkaline solubilization at $\mathrm{pH} 11$; RPI-3 and RPI-4, roe protein isolate adjusting at pH 4.5 and 5.5 , respectively, after alkaline solubilization at $\mathrm{pH} 12 ; \mathrm{Hb}$ hemoglobin

Values are means \pm standard deviation of duplicate determinations

Means with different letters within the same row are significantly different at $p<0.05$ by Duncan's multiple range test

${ }^{a}$ Based on dry weight

bessential amino acids for infant

'Hydrophobic amino acids 
respectively. Amino acids namely glutamic acid (13.14 g), aspartic acid (8.08 g) and arginine (5.76 g) were reported per $100 \mathrm{~g}$ roe protein of Channa roe protein concentrate (Narsing Rao et al. 2012).

NEAAs of RAIs were relatively higher than those data of FDC. Predominant essential amino acids (EAAs) of RAI-11 were leucine $(8.0 \%)$, lysine $(7.6 \%)$ and valine (6.7 \%), respectively. These were similar to those of RAI12 which had leucine $(7.5 \%)$, lysine $(7.3 \%)$ and valine (6.3 \%). EAAs/NEAAs ratio of RAI-11 (0.96) was higher than that of RAI-12 (0.89). From the result, total essential amino acid (isoleucine, leucine, lysine, methionine, phenylalanine, threonine, valine) content of RAI-11 (49.0\%) was higher than that of RAI-12 (47.1\%). However, EAAs content of RAIs (47.1-49.0\%) were lower than that of FDC (51.1 \%). Thus, EAAs/NEAAs ratio of RAIs (0.89-0.96) were lower than that (1.04) of FDC. RPIs were rich in glutamine, asparagine, leucine, and lysine which accounted for $12.4-12.7 \%, 9.1-9.3 \%, 8.8-9.4 \%$ and $8.3-8.9 \%$ of total amino acid, respectively. The hydrophobic amino acid content of RAIs and RPIs were similar in range of 45.4-46.3 \%. However, RAI was richer in proline and glycine than RPIs $(P<0.05)$. In the case of proline and glycine the difference may be due to the elimination of collagenous material during the protein recovery by the alkaline solubilization. Lysine content of RAIs and RPIs was similar to that (6.1 to $9.7 \%$ ) of pollock protein samples reported by Sathivel et al. (2006). RPIs and RAIs can be used as a nutritional supplement due to the content of essential amino acids composition.

\section{Mineral}

The mineral contents $(\mathrm{mg} / 100 \mathrm{~g})$ of FDC and RAIs and RPIs are given in Table 5. The main functions of essential minerals include skeletal structure, maintenance of colloidal system and regulation of acid-base equilibrium, and mineral also constitute important components of hormones, enzymes and enzyme activators (Belitz and Grosch 2001). The major mineral contents of RPIs and RAIs were $\mathrm{S}(591.4-715.7 \mathrm{mg} / 100 \mathrm{~g}) \mathrm{K}(36.2-130.6 \mathrm{mg} / 100 \mathrm{~g}), \mathrm{Na}$ (78.2-303.3 $\mathrm{mg} / 100 \mathrm{~g})$, and $\mathrm{Ca}(7.8-39.4 \mathrm{mg} / 100 \mathrm{~g})$. The $\mathrm{K}$ content of RPIs was found to be in ranged of $36.2-$ $68.5 \mathrm{mg} / 100 \mathrm{~g}$, respectively. Among RPIs, the RPI-4 $(\mathrm{pH} 12 / 5.5)$ had the highest content of $\mathrm{Na}(244.4 \mathrm{mg} /$

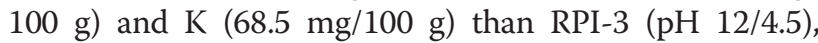
RPI-2 (pH 11/5.5) and RPI-1 (pH 11/4.5) $(P<0.05)$. However, Na content of RPIs was lower than that of crab (Gokoglu and Yerlikaya 2003), rainbow trout (Gokoglu et al. 2004) and fish based dishes (Martinez-Valverde et al. 2000). P content of RPIs (215.3-254.6 mg/100 g) was lower than that $(337.8 \mathrm{mg} / 100 \mathrm{~g})$ of rainbow trout reported for Gokoglu et al. (2004) and higher than that $(215.0-231.0 \mathrm{mg} / 100 \mathrm{~g})$ of European perch reported Orban et al. (2007). Mg content of RPI-2 and RPI-4 (32.3$21.4 \mathrm{mg} / 100 \mathrm{~g})$ were higher than those $(6.6-4.6 \mathrm{mg} / 100 \mathrm{~g})$ of RPI-1 and RPI-3 $(P<0.05)$. S and Ca content of RPIs were no significant difference $(P>0.05) . \mathrm{Na}, \mathrm{K}$ and $\mathrm{Mg}$ content of RAI-11 (213.0, 108.9 and $23.4 \mathrm{mg} / 100 \mathrm{~g}$, respectively) were lower than those $(303.3,130.6$ and $51.7 \mathrm{mg} / 100 \mathrm{~g}$, respectively) of RAI-12 $(P<0.05)$. These values were higher than RPIs $(P<0.05)$. This result is indicated that $\mathrm{Na}, \mathrm{K}$ and $\mathrm{Mg}$ content of RPIs could be eliminated during the alkaline solubilization process. $\mathrm{Mg}$ of RAIs was similar to that $(33.0-34.0 \mathrm{mg} / 100 \mathrm{~g})$ of sea bream (Orban et al. 2000) and that (25.1-33.6 mg/100 g) of Baltic herring (Tahvonen et al. 2000). But, P content of RAIs contained in range of $84.3-97.1 \mathrm{mg} / 100 \mathrm{~g}$ was lower than those of RPIs $(P<0.05)$ because of solubilization of $\mathrm{P}$ content for RAIs during alkaline solubilization process. $\mathrm{Ca}$ content of RAIs (39.4-37.2 mg/100 g, respectively) was

Table 5 Mineral contents (mg/100 g of sample) of FDC, RAls and RPIs prepared by ISP process and positive controls

\begin{tabular}{|c|c|c|c|c|c|c|c|c|c|}
\hline Sample & FDC & RAl-11 & RAI-12 & RPI-1 & $\mathrm{RPI}-2$ & RPI-3 & RPI-4 & Casein & $\mathrm{Hb}$ \\
\hline Moisture (\%) & 4.3 & 6.5 & 10.1 & 4.7 & 3.4 & 2.3 & 5.0 & 4.0 & 2.0 \\
\hline K & $1179.9 \pm 8.3 a$ & $108.9 \pm 3.9 d$ & $130.6 \pm 0.6 c$ & $36.2 \pm 1.7 \mathrm{~g}$ & $57.5 \pm 1.3 f$ & $51.6 \pm 1.7 f$ & $68.5 \pm 4.9 e$ & $912.0 \pm 12.3 b$ & $71.4 \pm 3.0 \mathrm{e}$ \\
\hline S & $992.3 \pm 92.6 b$ & $591.4 \pm 33.4 \mathrm{e}$ & $627.9 \pm 40.9 \mathrm{cde}$ & $609.2 \pm 40.9$ de & $715.7 \pm 26.9 c$ & $664.1 \pm 75.0$ cde & $698.9 \pm 73.9 \mathrm{~cd}$ & $1984.1 \pm 3.2 \mathrm{a}$ & $442.0 \pm 46.2 f$ \\
\hline $\mathrm{Na}$ & $376.2 \pm 2.1 b$ & $213.0 \pm 3.6 e$ & $303.3 \pm 3.7 c$ & $78.2 \pm 0.1 \mathrm{~h}$ & $123.7 \pm 1.0 \mathrm{~g}$ & $188.0 \pm 2.0 f$ & $244.4 \pm 4.2 d$ & $706.3 \pm 10.9 a$ & $212.6 \pm 1.8 \mathrm{e}$ \\
\hline P & $257.7 \pm 2.8 \mathrm{a}$ & $84.3 \pm 1.5 f$ & $97.1 \pm 1.4 \mathrm{e}$ & $254.6 \pm 2.5 a$ & $246.8 \pm 7.8 b$ & $235.7 \pm 1.2 \mathrm{c}$ & $215.3 \pm 1.6 \mathrm{~d}$ & $34.7 \pm 0.4 \mathrm{~g}$ & $29.1 \pm 0.3 \mathrm{~h}$ \\
\hline Mg & $66.8 \pm 0.4 a$ & $23.4 \pm 0.2 d$ & $51.7 \pm 0.5 b$ & $6.6 \pm 0.1 f$ & $32.3 \pm 0.6 c$ & $4.6 \pm 0.1 \mathrm{~g}$ & $21.4 \pm 0.0 \mathrm{e}$ & - & - \\
\hline $\mathrm{Zn}$ & $45.0 \pm 0.3 b$ & $42.8 \pm 0.3 c$ & $44.4 \pm 0.2 b$ & $23.2 \pm 0.4 d$ & $52.1 \pm 0.4 a$ & $23.0 \pm 0.2 d$ & $52.6 \pm 0.8 a$ & - & - \\
\hline $\mathrm{Ca}$ & $33.5 \pm 0.3 b$ & $39.4 \pm 1.0 \mathrm{~b}$ & $37.2 \pm 0.2 b$ & $7.8 \pm 0.1 d$ & $15.3 \mathrm{P} \pm 0.5 \mathrm{~cd}$ & $12.4 \pm 0.1 \mathrm{~cd}$ & $16.5 \pm 0.3 \mathrm{~cd}$ & $987.2 \pm 17.3 \mathrm{a}$ & $21.2 \pm 0.2 c$ \\
\hline $\mathrm{Fe}$ & $9.8 \pm 0.1 d$ & $5.8 \pm 0.1 e$ & $6.6 \pm 0.1 e$ & $12.9 \pm 0.3 b c$ & $11.9 \pm 0.1 \mathrm{c}$ & $13.5 \pm 0.2 b$ & $13.2 \pm 0.3 b$ & $4.8 \pm 0.0 f$ & $250.1 \pm 1.8 \mathrm{a}$ \\
\hline $\mathrm{Mn}$ & $0.1 \pm 0.0 c$ & $0.1 \pm 0.0 c$ & $0.0 \pm 0.0 \mathrm{~d}$ & $-0.1 \pm 0.0 \mathrm{e}$ & $0.0 \pm 0.0 \mathrm{~d}$ & $-0.1 \pm 0.0 \mathrm{e}$ & $0.0 \pm 0.0 \mathrm{~d}$ & $4.0 \pm 0.0 a$ & $0.4 \pm 0.0 b$ \\
\hline
\end{tabular}

FDC freeze-dried concentrate; RAI-11 and 12, roe alkaline insolubles after alkaline solubilization at pH 11 and 12, respectively; RPI-1, 2, 3 and 4, roe protein isolate adjusting at $\mathrm{pH} 4.5$ and 5.5, respectively after alkaline solubilization at $\mathrm{pH} 11$ and $12 ; \mathrm{Hb}$ hemoglobin

Values are means \pm standard deviation of triple determinations

Means with different letter within the same row are significantly different at $P<0.05$ by Duncan's multiple range test

-; not determined 
Table $6 L^{*}, a^{*}$ and $b^{*}$ color values, whiteness of FDC, RAls and RPIs by ISP process

\begin{tabular}{|c|c|c|c|c|c|c|c|}
\hline Hunter color & FDC & RAI-11 & RAI-12 & RPI-1 & RPI-2 & RPI-3 & RPI-4 \\
\hline$L^{*}$ & $59.2 \pm 0.1 d$ & $64.3 \pm 0.1 a$ & $63.7 \pm 0.1 b$ & $59.6 \pm 0.2 c$ & $57.2 \pm 0.2 f$ & $57.8 \pm 0.2 e$ & $57.7 \pm 0.2 e$ \\
\hline$a^{*}$ & $6.5 \pm 0.1 \mathrm{a}$ & $5.7 \pm 0.1 c$ & $5.9 \pm 0.0 b$ & $4.6 \pm 0.1 f$ & $5.6 \pm 0.1 c$ & $5.0 \pm 0.1 e$ & $5.5 \pm 0.10$ \\
\hline$b^{*}$ & $18.6 \pm 0.0 c$ & $19.5 \pm 0.4 b$ & $20.0 \pm 0.0 a$ & $16.4 \pm 0.1 e$ & $17.3 \pm 0.0 d$ & $16.2 \pm 0.0 \mathrm{e}$ & $17.4 \pm 0.1 d$ \\
\hline$\Delta \mathrm{E}$ & $42.3 \pm 0.1 b$ & $38.2 \pm 0.6 e$ & $38.9 \pm 0.1 d$ & $40.7 \pm 0.2 c$ & $43.3 \pm 0.2 a$ & $42.4 \pm 0.2 d$ & $43.0 \pm 0.1 a$ \\
\hline Whiteness & $54.7 \pm 0.1 d$ & $58.9 \pm 0.3 a$ & $58.1 \pm 0.1 b$ & $56.2 \pm 0.2 c$ & $53.5 \pm 0.2 f$ & $54.5 \pm 0.2 b$ & $53.9 \pm 0.1 €$ \\
\hline
\end{tabular}

FDC freeze-dried concentrate; RAI-11 and 12, roe alkaline insolubles after alkaline solubilization at pH 11 and 12, respectively; RPI-1, 2, 3 and 4, roe protein isolate adjusting at $\mathrm{pH} 4.5$ and 5.5, respectively after alkaline solubilization at $\mathrm{pH} 11$ and $12 ; \mathrm{Hb}$ hemoglobin

Values are means \pm standard deviation of triplicate determinations

Means with different letters within the same row are significantly different at $p<0.05$ by Duncan's multiple range test

significantly higher $(P<0.05)$ than those found in RPIs. During the ISP process, $\mathrm{K}, \mathrm{Na}, \mathrm{Ca}$ and $\mathrm{S}$ content of RPIs and RAIs were significantly lower than those (912.0, 706.3, 987.2 and $1984.1 \mathrm{mg} / 100 \mathrm{~g}$, respectively) of casein $(P<0.05)$. In case of hemoglobin, similar results were observed in RAIs and RPIs except for Fe and S. Potentially, the RAIs as recovered insoluble may be useful in animal feeds as a mineral additive due to the relatively high concentration of minerals ( $\mathrm{Ca}, \mathrm{Mg}$, and $\mathrm{K}$ ).

\section{Hunter color}

The color properties of FDC, RAIs and RPIs are presented in Table 6. $\mathrm{L}^{*}, \mathrm{a}^{*}$, and $\mathrm{b}^{*}$ of RAIs were higher than RPIs $(P<0.05)$. Among the RPIs, RPI-1 was the lightest with $L^{*}$ value (59.6) followed by RPI-3 (57.8) RPI-4 (57.7) and, RPI-2 (57.2), respectively $(P<0.05)$. RPI-1 and RPI-3 had the lower $b^{*}$ value of 16.4 and 16.2, respectively than those (17.3 and 17.4, respectively) of RPI-2 and RPI-4 $(P<0.05)$. RPI-2 and RPI- 4 had higher $\mathrm{a}^{*}$ value (5.6 and 5.5, respectively) than that (4.6 and 5.0, respectively) of RPI-1 and RPI-3 $(P<0.05)$. However, RPI1 and RPI-3 had higher whiteness values (56.2 and 54.5, respectively) than the other RPIs (53.5 for RPI-2 and 53.9 for RPI-4). RAI-11 was lightest $(P<0.05)$ with $L^{*}$ value of 64.3 than that (63.7) of RAI-12. $\mathrm{a}^{*}, \mathrm{~b}^{*}$ and $\Delta \mathrm{E}$ values of RAI-11 (5.7, 19.5 and 38.2 respectively) were slightly lower than those of RAI-12. Whiteness value of RAI-11 (58.9) was higher than that $(58.1)$ of RAI-12 $(P<0.05)$. This different in color could be due to the separation pigment content caused by ISP process. Among the RAIs and RPIs, RAI-11 could be more useful as a food ingredient because of high value of whiteness.

\section{SDS-PAGE}

SDS-PAGE patterns of FDC, RAIs, RPIs, RPWs, RAIWWs and RPI-WWs obtained by ISP process are shown in Fig. 2. Protein with a molecular weight (MW) ranged from 37 to $50 \mathrm{~K}$ was dominant in RAI-11 and RAI-12.

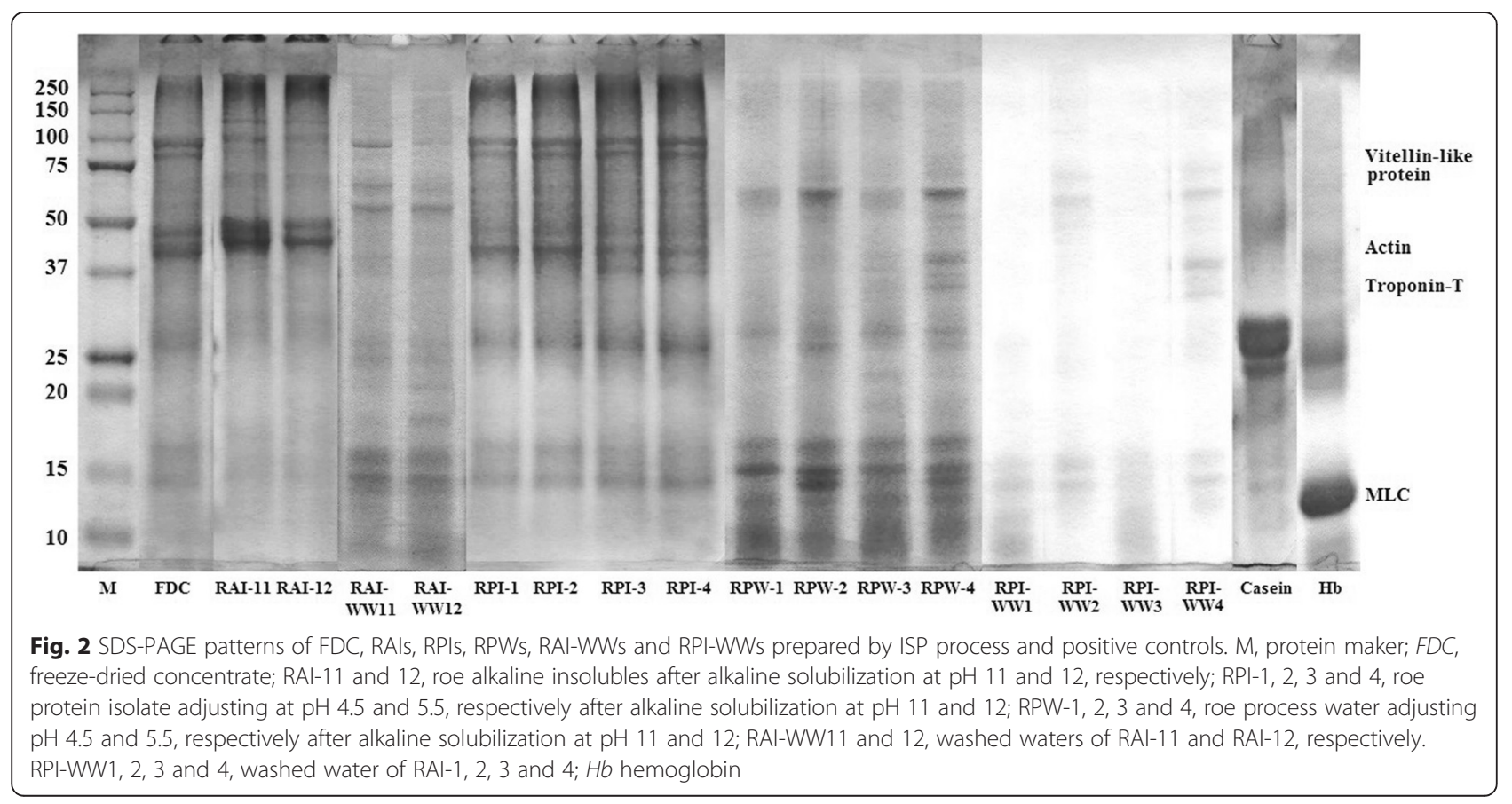


Other protein bands in range of $100-150 \mathrm{~K}, 25-37 \mathrm{~K}$ and $15-20 \mathrm{~K}$, respectively were also observed. There was no difference between RAIs except for protein band in range of 37-50 K where RAI-11 was clearer than that of RAI12. The protein with a MW of $97 \mathrm{kDa}$ might be a vitellinlike protein, which was found in salmon Oncorhynchus keta and sturgeon Acipenser transmontanus roes (Al-Holy and Rasco 2006). Similar proteins with MW of 32.5, 29 and $32.5 \mathrm{~K}$ were found in skipjack Kasuwonous pelamis, tonggol Thunnus tonggol and bonito Euthynnus affinis roe, respectively reported Intarasirisawat et al. (2011). Those proteins might be ovomucoid (Al-Holy and Rasco 2006) or phosvitin (Losso et al. 1993). Generally, different roe samples showed different electrophoretic patterns, indicating the differences in protein compositions among all samples (Intarasirisawat et al. 2011). Compared with FDC, low molecular protein bands (0-15 K) of RAIs were more faint than those of FDC that because a little protein compounds and others were transferred to RAI-WWs. Washed soluble proteins were moved on RAI-WW11 and RAI-WW12. Overall, RAI-WW11 had lower molecular protein bands than RAI-WW12 because of difference on solubilization condition during alkaline solubilization and precipitation (ISP). Prominent protein bands of RPI-1-4 were in range of 75-100 K, 37-50 K, 15-20 K, and $10 \mathrm{~K}$ respectively. A similar SDS-PAGE pattern of lower molecular weight protein $(10 \mathrm{~K})$ was observed in meriga roe hydrolysate (Chalamaiah et al. 2010). This result was also similar to hemoglobin which protein band observed in range of around $25 \mathrm{~K}$ and $10-15 \mathrm{~K}$, respectively. Protein band of casein with molecular weight ranged $25-37 \mathrm{~K}$ was clearer than that of RPIs. Protein band of RPIs in range from 50 to 75 were faint because those proteins already been washed and moved to RPI-WWWs. Protein band of RPWs with molecular weight of $10 \mathrm{~K}$ were was clearer than that of RPI. This result is indicated that acid was affected to degradation on aggregation and association of low molecular weight. Al-Holy and Rasco (2006) reported that three prominent proteins of salmon caviar had MW of 96,20 and $10 \mathrm{~K}$, which could be vitellin and possibly lysozyme or phosvitin. Protein with a MW of approximately $27 \mathrm{~K}$ in the soluble fraction of sturgeon caviar may possibly represent ovomucoid, a glycoprotein, which normally has a MW of 27-29 K (Al-Holy and Rasco 2006). For RAIs and RPIs, new protein bands with molecular weight over the $250 \mathrm{~K}$ were formed instead of FDC. Azadian et al. (2012) reported that this can be explained by the dissociation of high molecular weight myosin and association of the protein to form a high molecular weight.

\section{Conclusion}

The roe of marine sources are the most underutilized fish by-products, which have considerable chance for value-addition to produce food and feed. This study was to investigate the chemical compositions, amino acid profile, mineral profile, color from yellowfin tuna protein roe isolate and second by-products with isoelectric solubilization/precipitation using basic and acidic $\mathrm{pH}$ treatments. RPIs and RAIs can be used as a nutritional supplement due to the content of essential amino acids composition. The RAIs as recovered insoluble may be useful in animal feeds as a mineral additive due to the relatively high concentration of minerals $(\mathrm{Ca}, \mathrm{Mg}$, and $\mathrm{K})$. Therefore, yellowfin tuna roe isolate could be a promising source of valuable nutrients for human food and animal feeds.

\section{Acknowledgements}

This research was supported by Basic Science Research Program through the National Research Foundation of Korea(NRF) funded by the Ministry of Education(NRF-2014R1A1A4A01008620).

\section{Authors' contributions}

$\mathrm{HJL}$ and SHP carried out the preparation of protein isolates, participated in the analysis of chemical compositions and drafted the manuscript. ISY G-WL and SYP participated in searching and screening references and performed the statistical analysis and carried out the SDS-PAGE. J-SK and MSH conceived of the study, and participated in its design and coordination and helped to draft the manuscript. All authors read and approved the final manuscript.

\section{Competing interests}

The authors declare that they have no competing interests.

\section{Author details}

'Department of Food and Nutrition/Institute of Marine Industry, Gyeongsang National University, Jinju 52828, Korea. ${ }^{2}$ Department of Seafood Science and Technology/Institute of Marine Industry, Gyeongsang National University,

Tongyeong 53064, Korea.

Received: 26 November 2015 Accepted: 21 March 2016

Published online: 25 May 2016

\section{References}

Agboola S, Ng D, Mills D. Characterization and functional properties of Australia rice protein isolates. J Cereal Sci. 2005;41:283-90.

Al-Holy MA, Rasco BA. Characterisation of salmon (Oncorhynchus keta) and sturgeon (Acipenser transmontanus) caviar proteins. J Food Biochem. 2006:30:422-8.

AOAC (Association of Analytical Chemists). Official Methods of Analysis. 16th ed. Washington DC: Association of Analytical Chemists; 1995. p. 69-74.

Azadian M, Nasab MM, Abedi E. Comparison of functional properties and SDSPAGE patterns between fish protein isolate and surimi produced from silver carp. Eur Food Res Technol. 2012;235:83-90.

Belitz HD and Grosch W. 2001. Schieberle, P. Lehrbuch der Lebensmittelchemie, ISBN 3-540-41096-1 5. Aufl. Springer-Verlag Berlin, Heidelberg, New York

Chalamaiah M, Narsing Rao G, Govardhana Rao D, Jyothirmayi T. Protein hydrolysates from meriga (Cirrhinus mrigala) egg and evaluation of their functional properties. Food Chem. 2010;120:652-7.

Chalamaiah M, Balaswamy K, Narsing Rao G, Prabhakara Rao PG, Jyothirmayi T. Chemical composition and functional properties of mrigal (Cirrhinus mrigala) egg protein concentrates and their application in pasta. J Food Technol. 2013;50:514-20.

Chanarat S, Benjakul S. Impact of microbial transglutaminase on gelling properties of Indian mackerel fish protein isolates. Food Chem. 2013;136:929-37.

Chen YC, Jaczynski J. Gelation of protein recovered from Antarctic krill (Euphausia superba) by isoelectric solubilization/precipitation as affected by function additives. J Agric Food Chem. 2007a;55:1814-22.

Chen YC, Jaczynski J. Protein recovery from rainbow trout (Oncorhynchus mykiss) processing by-products via isoelectric solubilization/precipitation and its 
gelation properties as affected by functional additives. J Agric Food Chem. 2007b;55:9079-88.

Collette BB, Nauen CE. FAO Species Catalogue. Vol. 2 Scombrids of the World: An Annotated and Illustrated Catalogue of Tunas, Mackerels, Bonitos, and Related Species Known to Date. Rome: FAO; 1983. p. 137. Fish. Synop., 125.

Foh MBK, Wenshui X, Amadou I, Jiang Q. Influence of pH shift on functional properties of protein isolated of tilapia (Oreochromis niloticus) muscles and of soy protein isolate. Food Bioprocess Technol. 2012;5:2192-200.

Gokoglu N, Yerlikaya P. Determination of proximate composition and mineral contents of blue crab (Callinectes sapidus) and swim crab (Portunus pelagicus) caught off the Gulf of Antalya. Food Chem. 2003;80:495-8.

Gokoglu N, Yerlikaya P, Cengiz E. Effect of cooking methods on the proximate composition and mineral contents of rainbow trout (Oncorhynchus mykiss). Food Chem. 2004;84:19-22.

Horax R, Hettiarachchy NS, Chen P, Jalaluddin M. Preparation and characterization of protein isolate from cowpea (Vigna unguiculata L. Walp.). J Food Sci. 2004;69:FCT114-8.

Horax R, Hettiarachchy N, Kannan A, Chen P. Protein extraction ptimisation, characterisation, and functionalities of protein isolate from bitter melon (Momordica charantia) seed. Food Chem. 2011;124:545-50.

Huda N, Abdullah A, Babji AS. Functional properties of surimi powder from three Malaysian marine fish. Int J Food Sci Technol. 2001;36:401-6.

Intarasirisawat R, Benjakul S, Visessanguan W. Chemical compositions of the roes from skipjack, tongol and bonito. Food Chem. 2011;124:1328-34.

Ji SJ, Lee JS, Shin JH, Park KH, Kim JS, Kim KS, Heu MS. Distribution of protease inhibitors from fish eggs as seafood processing byproducts. Kor J Fish Aquat Sci. 2011;44:8-17.

Ju ZY, Hettiarachchy NS, Rath N. Extraction, denaturation, and hydrophobic properties of rice flour proteins. J Food Sci. 2001;66:229-32.

Kim HJ, Kim KH, Song SM, Kim IY, Park SH, Gu EJ, Lee HJ, Kim JS, Heu MS. Fractionation and characterization of protease inhibitors from fish eggs based on protein solubility. Kor J Fish Aquat Sci. 2013a;46:119-28.

Kim JS, Kim KH, Kim HJ, Kim MJ, Park SH, Lee HJ, Heu MS. Chromatographic fractionation of protease inhibitors from fish eggs. Kor J Fish Aquat Sci. 2013b;46:351-8.

Klomklao S, Benjakul S, Kishimura H. Optimum extraction and recovery of trypsin inhibitor from yellowfin tuna (Thunnus albacores) roe and its biochemical properties. Int J Food Sci Technol. 2013;49:168-73.

Kristinsson HG, Ingadottir B. Recovery and properties of muscle proteins extracted from tilapia (Oreochromis niloticus) light muscle by pH shift processing. J Food Sci. 2006;71:132-41.

Kristinsson HG, Rasco BA. Biochemical and functional properties of Atlantic salmon (Salmo salar) muscle proteins hydrolyzed with various alkaline proteases. J Agric Food Chem. 2000;48:657-66.

Laemmli UK. Cleavage of structural proteins during the assembly of the head of bacteriophage T4. Nature. 1970;227:680-5.

Losso JN, Bogumil R, Nakai S. Comparative studies of phosvitin from chicken and salmon egg yolk. Comp Biochem Physiol B. 1993;106:919-23.

Lowry OH, Rosebrough NJ, Farr AL, Randall RJ. Protein measurement with the Folin phenol reagent. J Biol Chem. 1951;193:265-75.

Martinez-Valverde I, Periago MJ, Santaella M, Ros G. The content and nutritional significance of minerals on fish flesh in the presence and absence of bone. Food Chem. 2000;71:503-9.

Mireles DeWitt CA, Gomez G, James JM. Protein extraction from beef heart using acid solubilization. J Food Sci. 2002;67:3335-41.

Narsing Rao G, Balaswamy K, Satyanarayana A, Prabhakara RP. Physico-chemical, amino acid composition, functional and antioxidant properties of roe protein concentrates obtained from Channa striatus and Lates calcarifer. Food chem. 2012;132:1171-6.

Nolsøe $H$, Undeland I. The acid and alkaline solubilization process for the isolation of muscle proteins. Food Bioprocess Technol. 2009;2:1-27.

Orban E, Di Lena G, Ricelli A, Paoletti F, Casini I, Gambelli L, Caproni R. Quality characteristics of sharpsnout sea bream (Diplodus puntazzo) from different intensive rearing systems. Food Chem. 2000;70:27-32.

Orban E, Nevigato T, Masci M, Di Lena G, Casini I, Caproni R, Gambelli L, De angelis P, Rampacci M. Nutritional quality and safety of European perch (Perca fluviatilis) from three lakes of central Italy. Food Chem. 2007;100:482-90.

Paraman I, Hettiarachchy NS, Schaefer C, Beck MI. Hydrophobicity, solubility, and emulsifying properties of enzyme-modified rice endosperm protein. Cereal Chem. 2007;84:343-9.
Pires C, Costa S, Batista AP, Nunes MC, Raymundo A, Batista I. Properties of protein powder prepared from Cape hake by-products. J Food Eng. 2012;108:268-75.

Sathivel S, Bechtel PJ. Properties of soluble protein powders from Alaska pollock (Theragra chalcogramma). Int J Food Sci Technol. 2006;41:520-9.

Sathivel S, Bechtel PJ, Babbitt JK, Prinyawiwatkul W, Negulescu II, Reppond KD. Properties of protein powders from arrowtooth flounder (Atheresthes stomias) and herring (Clupea harengus) byproducts. J Agric Food Chem. 2004;52:5040-6.

Sathivel S, Bechtel PJ, Babbitt JK, Prinyawiwatkul W, Patterson M. Functional, nutritional, and rheological properties of protein powders from arrowtooth flounder and their application in mayonnaise. J Food Sci. 2005;70:E57-63.

Sathivel S, Bechtel PJ, Prinyawiwatkul W. Physicochemical and rheological properties of salmon protein powders. Int J Food Eng. 2006;2:2.

Sathivel S, Yin H, Bechtel PJ, King JM. Physical and nutritional properties of catfish roe spray dried protein powder and its application in an emulsion system. J Food Eng. 2009;95:76-81.

Shaviklo GR, Thorkelsson G, Arason S, Sveinsdottir K. Characteristics of freezedried fish protein isolated from saithe (Pollachius virens). J Food Sci Technol. 2011:49:309-18.

Tahergorabi R, Beamer SK, Matak KE, Jaczynski J. Isoelectric solubilization/ precipitation as a means to recover protein isolate from Striped Bass (Morone saxatilis) and Its physicochemical properties in a nutraceutical seafood product. J Agric Food Chem. 2012;60:5979-87.

Tahvonen R, Aro T, Nurmi J, Kallio H. Mineral content in Baltic herring and Baltic herring products. J Food Compos Anal. 2000;13:893-903.

Zudaire I, Murua H, Grande M, Korta M, Arrizabalaga H, Areso JJ, et al. Fecundity regulation strategy of the yellowfin tuna (Thunnus albacares) in the Western Indian Ocean. Fish Res. 2013;138:80-8.

\section{Submit your next manuscript to BioMed Central and we will help you at every step:}

- We accept pre-submission inquiries

- Our selector tool helps you to find the most relevant journal

- We provide round the clock customer support

- Convenient online submission

- Thorough peer review

- Inclusion in PubMed and all major indexing services

- Maximum visibility for your research

Submit your manuscript at www.biomedcentral.com/submit
( ) BioMed Central 